Živorad Gligorijević ${ }^{1}$

Faculty of Economics University of Nis

Enes Ćorović ${ }^{2}$

State University of Novi Pazar department of economic science

Aleksandar Manasijević ${ }^{3}$

Faculty of Economics University of Nis
ORIGINAL SCIENTIFIC ARTICLE doi: 10.5937/ekonomika2002037G

Received: January, 25. 2020. Accepted: February, 27. 2020.

\title{
STRUCTURAL CHANGES AND ECONOMIC GROWTH OF THE REPUBLIC OF SERBIA: A CONTRIBUTION TO THE ECONOMIC HISTORY OF THE SECOND HALF OF THE 20 ${ }^{\text {th }}$ CENTURY
}

\begin{abstract}
The main characteristic of the economic development of the Republic of Serbia during the second half of the 20th century was contained in the development of industry, which, according to all relevant indicators, led to rapid and very large structural changes that were accompanied by high rates of economic growth. However, at the very beginning of the observed period, large structural mismatches occurred in the economy of the Republic of Serbia as a consequence of the mentioned changes. Due to their continuous presence throughout the analyzed period, these mismatches represent a basic characteristic of development processes, and also a confirmation (obtained through research on the example of the Republic of Serbia) of a theoretically established cause and effect relationship between structural changes and economic growth.
\end{abstract}

Key words: Economy, Economic history, structural changes, economic growth, the Republic of Serbia

JEL classification: O11, O14, O25, O40, P23, P24.

\section{СТРУКТУРНЕ ПРОМЕНЕ И ПРИВРЕДНИ РАСТ РЕПУБЛИКЕ СРБИЈЕ: ПРИЛОГ ЗА ПРИВРЕДНУ ИСТОРИЈУ ДРУГЕ ПОЛОВИНЕ 20. ВЕКА}

\begin{abstract}
Апстракт
Основна карактеристика привредног развоја Републике Србије, током друге половине 20. века, садржана је у развоју индустрије која је, према свим релевантним показатељима, довела до брзих и веома крупних структурних промена које су биле праћене високим стопама привредног раста. Међутим,
\end{abstract}

\footnotetext{
${ }^{1}$ prof.z.gligorijevic@gmail.com, ORCID ID 0000-0003-0055-5228

2 encorovic@np.ac.rs, ORCID ID 0000-0002-3458-4548

3 aleksandar.manasijevic.eknfak@gmail.com, ORCID ID 0000-0002-2268-8403
} 
на самом почетку посматраног периода у привреди Републике Србије, као последица поменутих промена, настале су крупне структурне неусклађености. Због њиховог континуираног присуства у целокупном анализираном периоду, те неусклађености представљају основну карактеристику развојних процеса, а исто тако, и потврду (добијену путем истраживања на примеру Републике Србије) теоријски установљене узрочно-последичне везе између структурних промена и привредног раста.

Кључне речи: Привреда, привредна историја, структурне промене, привредни раст, Република Србија.

\section{Introduction}

The main characteristics of economic development of the Republic of Serbia in the period 1947-2000 involve major structural changes, as well as changes in the rate of economic growth. Moreover, the most significant development features, in the period 1947-1990 are rapid and profound structural changes caused by high rates of economic growth. However, in the last two decades of the observed period, the Republic of Serbia faced adverse developments. Unfavorable development tendencies, under extremely unstable macroeconomic conditions (high trade deficit and galloping inflation rate), marked the functioning of the economy of the Republic of Serbia during the 1990s.

At the same time, the negative effects of the aforementioned economic trends were exacerbated by the effects of non-economic factors (collapse of the common state, sanctions by the international community, etc.), which caused huge direct and indirect losses, primarily through the reduction of gross domestic product and further destabilisation of economic flows. The partial recovery occurring after this period stagnated due to the bombing of the country by NATO countries in 1999.

Having in mind the above facts, the article aims to analyse the structural changes and trends of economic growth of the Republic of Serbia over a long period of time (during the second half of the 20th century), by means of the reference statistical material, trying as well to highlight the key consequences of the cause-and-effect relationship between these phenomena.

\section{Research on structural change and economic growth}

The terms 'economic structure' and 'structural change' represent categories that are widely used in economic research, although including different meanings and interpretations. 'When conscientious, meticulous, Fritz Machlup tried to retrieve different meanings of the word 'structure' from the scientific economic literature, he found a total of 25 meanings, 10 of which were clear and definite, 9 less clear, and 6 with some tendentious, suggestive meanings' (Stojanovic, 1972, p. 31).

There is a strong, two-way, cause-and-effect link between structural change and economic growth: a structural change is the most important consequence of economic growth, but at the same time, one of the most significant factors related to it. '... Structural changes are a central element of the development process and an essential element of the 
growth model, they can slow down growth if they are slow or inefficient, but they can also contribute to growth if resource allocation is improved' (Kuznets, 1957). Therefore, the analyses of economic structure and structural changes during the 20th century were, for the most part, tied to different theories and models of growth.

The first model of economic growth was formulated shortly after World War II. It is a one-factor model of economic growth that observes the role of investment in achieving high growth rates. This model assumes that growth in production volumes is the result of capital accumulation, while other factors (employment and technological change) are neglected (Domar, 1947; Harod, 1948).

In numerous studies related to structural changes, during the 1950s and 1960s, economic growth was presented, in the historical context, as a result of the changing structure of the economic system. In two-sector model, economic growth is explained by the shift of labour from the agricultural sector to the industrial sector (Lewis, 1954). In the analysis of the economic growth of European countries, during the first half of the twentieth century, economic growth and structural change are also considered by using a historical approach. The results of the analysis show that long-term economic growth is related to a number of structural changes, such as: mechanisation, changes in the inputoutput ratio, changes in distribution and consumption, changes in import and export, and redistribution of labour between different sectors (Svennilson, 1954).

The neoclassical model of growth, which, in many opinions, represents a particular contribution to the development of economic science, used the analysis of the production function as a starting point. The author of the model came to the conclusion that the basic factors of growth were: an increase in the workforce (population growth), an increase in capital (accumulation and investment) and an improvement in technology (Solow, 1956).

By studying the development patterns of different countries the strong links between the growth of industrial production and economic growth at the level of the whole economy were emphasised. In order to identify the determinants of structural changes the analysis included one of the first applications of econometric methods. By doing so, the following basic factors that determine the economic growth of a country were included: the size of the country, geographical location and natural resources (Chenery, 1960).

Changes in the structure of national economies, from a historical point of view, occurred as an integral part of the process of diversification, the development of human creativity and their needs. Because of that, the dynamics of the change in the participation of individual economic sectors in the creation of GDP were different depending on the technical and technological progress and its influence on the activities within these sectors. Accordingly, in the late 1970s, many authors, engaged in the study of structural changes, began to largely analyse the role of technical and technological progress in the process of structural transformation: technological innovation (Kuznets, 1971) and the technological gap between developed and less developed countries (Abramowitz, 1986).

The economic crisis in developed countries during the 1970s and early 1980s, which, according to the majority of authors, had a structural character, initiated the emergence of more empirical research into the causes and desirable directions of structural change in those countries. The basis of these studies involved long statistical series of growth of individual sectors of the economy and individual branches and groups within. In comparison, these studies were, to a far greater extent, analytical, applying specially designed models and aimed at confirming the existence of a two-way cause-and-effect 
relationship between structural change and economic growth (Chenery, Robinson, \& Syrquin, 1986; Chatterjee, 1995; Fosu, 2010).

Structural change is an extremely complex phenomenon that should enable economic growth if appropriate changes are implemented in society (changes in the structure of production and employment etc.). In this sense, structural changes are referred to as changes in the composite structure of production, employment, exports, and so on (Landesman, 2000).

Economic growth, in individual economic sectors, occurs at irregular stages, with the aim of changing the growth rate of the total factor productivity of the sector. In addition, structural changes imply, among other things, changes in the participation of employees in individual sectors, and therefore, it is necessary, in the long run, to make changes in compliance with changes in the education system (Ngai \& Christopher, 2007).

Structural changes and economic growth in the Republic of Serbia during the second half of the 20th century was a subject of particular interest in economic research. Hence, considerable attention was paid to: theoretical analysis of factors and models of economic growth (Čobeljic, 1972; Stojanovic, 1977), structural changes that led to the emergence of serious discrepancies in the 1960s between the production of raw materials and energy, on the one hand, and processing capacity, on the other hand (Gligorijević, 1984; Rosić, 2002), the pace of economic growth and structural changes in the threesector model (Aranđelović \& Gligorijević, 2008), structural changes and a new model of economic growth (Gligorijević \& Ćorović, 2019) and so on.

\section{Structural changes an economic growth of the Republic of Serbia in the period 1947-1990}

The economic structure of the Republic of Serbia after the Second World War was formed under the influence of industrial development and industrialisation as a general development concept of the Socialist Federal Republic of Yugoslavia. Until the early 1970s, this development model had functioned as a unified and plan-coordinated nationwide development process. However, after the adoption of the constitutional amendments in 1971, and especially the 1974 Constitution, until the final dissolution of the state in the early 1990s, the economic development of the individual republics began to take on the characteristics of autarchic development.

Industrialisation in the Republic of Serbia, with its primary focus on the development of heavy industry, according to all relevant indicators, has led to rapid and profound structural changes, which, in the first decade of post-war development, were accompanied by high rates of economic growth. However, the emergence and deepening of structural disproportions (sectoral and regional) in the early 1960s raised the question of evaluating the applied model. The key dilemmas are related to the developmental potential of accelerated industrialisation and the legitimate production of structural discrepancies, in the economy as a whole, and in the industry in particular (Gligorijević, 1984), '... as germs to create barriers to future development. In line with the above, there are opinions that development cannot be highly valued till the end of the 1970s' (Marsenic, 2003, 97). 
During the observed period (from 1947 to 1990), the GDP of the economy of the Republic of Serbia was growing at an average annual rate of $4.9 \%$ and it was more than sevenfolded by the base year (index 748), at the same time, the GDP per capita quadrupled (index 500), corresponding to an average annual growth rate of $3.9 \%$. In addition, in the late 1980s, GDP per capita was, at the official exchange rate, proximatally about US \$ 2,500 and more than US $\$ 5,500$ in terms of purchasing power.

The reached dynamics of macroeconomic aggregates was the result of different growth rates of certain elements of the economic structure. The social sector had significantly higher growth dynamics than the private sector, so its share in the GDP increased more than tenfold in the observed period, while private sector share increased 2.6 times.

If analised by sectors of economy, the fastest growth was achieved in the industry, whose GDP in 1989 was almost eighteen times higher than in 1947. The highest growth of the industrial production was recorded in the period from 1953 to 1965 , when the average annual growth rate was 13\% (Drobnjak, 2013). Agricultural production's annual growth rate was $3.1 \%$ between 1947 and 1989, so its total growth tripled.

These differences in the dynamics of growth of individual elements, led to significant changes in the economic structure of the Republic of Serbia (Table 1). The social sector, from $57.4 \%$ in 1955 , increased its relative share in the creation of the GDP to $85.1 \%$ in 1989, while the private sector stabilised its relative share at the level of $14.9 \%$.

Table 1: Economic structure of the Republic of Serbia by sectors from 1955 to 1989

\begin{tabular}{|l|l|l|l|l|l|}
\hline Sectors & $\mathbf{1 9 5 5}$ & $\mathbf{1 9 6 5}$ & $\mathbf{1 9 7 5}$ & $\mathbf{1 9 8 5}$ & $\mathbf{1 9 8 9}$ \\
\hline Idustries - total & 100,0 & 100,0 & 100,0 & 100,0 & 100,0 \\
\hline Social property & 57,4 & 76,7 & 80,5 & 85,0 & 85,1 \\
\hline Private property & 42,6 & 23,3 & 29,5 & 15,0 & 14,9 \\
\hline Primary industries & $\mathbf{4 2 , 6}$ & $\mathbf{2 7 , 5}$ & $\mathbf{2 1 , 9}$ & $\mathbf{1 8 , 2}$ & $\mathbf{1 8 , 9}$ \\
\hline Agriculture and fisheries & 41,7 & 26,6 & 21,2 & 17,5 & 18,2 \\
\hline Water management & 0,2 & 0,4 & 0,4 & 0,4 & 0,4 \\
\hline Forestry & 0,7 & 0,5 & 0,3 & 0,3 & 0,3 \\
\hline Secundary industries & $\mathbf{3 2 , 7}$ & $\mathbf{4 6 , 1}$ & $\mathbf{4 3 , 1}$ & $\mathbf{5 2 , 7}$ & $\mathbf{5 3 , 0}$ \\
\hline Industry and mining & 18,3 & 30,7 & 34,6 & 42,7 & 44,5 \\
\hline Construction & 8,8 & 9,6 & 5,7 & 7,3 & 6,3 \\
\hline Craftsmanship & 5,6 & 5,8 & 2,8 & 2,7 & 2,2 \\
\hline Tertiary industries & $\mathbf{2 1 , 3}$ & $\mathbf{2 5 , 4}$ & $\mathbf{2 7 , 6}$ & $\mathbf{2 5 , 2}$ & $\mathbf{2 4 , 2}$ \\
\hline Traffic and connections & 6,3 & 6,9 & 7,6 & 7,0 & 7,9 \\
\hline Trade & 11,1 & 16,0 & 17,8 & 16,3 & 14,8 \\
\hline Catering and tourism & 3,9 & 2,5 & 2,2 & 1,9 & 1,5 \\
\hline Other industries & $\mathbf{3 , 4}$ & $\mathbf{1 , 0}$ & $\mathbf{7 , 4}$ & $\mathbf{3 , 9}$ & $\mathbf{3 , 9}$ \\
\hline
\end{tabular}

Source: Federal Bureau of Statistics, Statistical Yearbook of Yugoslavia 1976, 1977, 1987, 1991.

The most significant changes occurred in the sectoral structure of the GDP. Secondary idustries, led by industry, were a key driver of economic growth. They increased their relative share in the creation of the GDP from $32.7 \%$ in 1955 to $53 \%$ in 1989. Primary industries drastically reduced their relative share in the creation of the GDP, from $42.6 \%$ in 1955 to $18.9 \%$ in 1989 . Tertiary industries were characterised by a slight uneven movement of the relative share in the creation of the GDP, with the largest share of trade.

According to the above data, the fastest changes in the structure of the economy had been made in the period until the mid 1960s, which was characterised by accelerated 
progress of the economy and society in general. In the early 1960s, the relative share of agriculture and industry in the creation of the GDP appeared, and then, with the absolute increase in production in both sectors, a more dynamic growth of the industry increased its relative share. The tertiary industries, taken as a whole, increased relative share in the structure of the GDP from $21.3 \%$ in 1955 to $25.2 \%$ in 1985 , while in 1989 its relative share was $24.2 \%$.

Structural changes in the economy of the Republic of Serbia during this period resulted in an increase in the relative share of the industry in the creation of GDP at the expense of share, above all, in agriculture. However, the change in the relationship between the two sectors was a large and a rapid one. Therefore, adequate internal changes that would make this transformation structurally complete and developmentally efficient were not made. This is best evidenced by the course of structural changes in the industry sector (Gligorijević \& Ćorović. 2019).

\section{Structural changes an economic growth of the Republic of Serbia in the period 1990-2000}

The economy of the Republic of Serbia, during the 1990s, was marked by the continuation of unfavourable development tendencies created in the previous decade, extremely unstable macroeconomic conditions, but also by the action of numerous noneconomic factors.

After a long period of stagnation in the 1980 s, the industrial production fell below $10 \%$ in 1990 . This, with the decrease in the volume of activities in other sectors, led to the beginning of the recessionary phase and the fall of the GDP in that year by almost 8\% (Statistical Yearbook of Serbia, 2004). After a period of forced repayment of the external debt and a positive current account balance, the economy reentered the external imbalance with a trade deficit of more than US \$ 1.6 billion. Due to the lack of its own accumulation and limitations in external (foreign) borrowing, the already present tendency of declining investments continued.

The expressive macroeconomic instability, in the late 1980s and early 1990s, had its origins in a fundamental imbalance between available GDP and consumption. This was particularly evident in the conditions of a drastic decline in economic activity, and in the absence of real sources for filling the state budget. Due to the inability to finance the high deficit by borrowing abroad, the primary issue, ie inflationary budget financing, was conducted.

As a consequence of internal structural imbalances, the emergence of inflation is linked to the emergence of economic stagnation in the early 1980s. Inflation had been galloping over the years: in 1989 it stood at 1,256\%, while in 1990 it dropped to near $700 \%$, and $221 \%$ in 1991 . In 1992 , inflation was at the level of over $55 \%$ per month, and in 1993 over 1,000\% per month, while in December of the same year it reached the level of 180,000\% (Aranđelović \& Gligorijević, 2008, 211).

The negative effect of hyperinflation on the economy of the Republic of Serbia, at the same time, was exacerbated by the influence of non-economic factors. With the breakup of the common state, several decades of economic planned structural links 
between the republic members of the Socialist Federal Republic of Yugoslavia broke off. In addition to the loss of a large part of the domestic market for placement of final products, significant supply channels of raw materials were discontinued, which increased the already high import dependence of the manufacturing industry of the Republic of Serbia.

Along with the disintegration of the SFRY and the creation of independent states from the former republics, international sanctions were imposed on the Federal Republic of Yugoslavia. First, at the end of 1991, the European Community imposed economic sanctions, while, in the following year, the UN Security Council Resolution imposed a full trade embargo, with a ban on oil deliveries and a suspension of traffic across the territory of the Federal Republic of Yugoslavia.

Sanctions, in the short term, caused enormous negative macroeconomic effects (direct and indirect), primarily through the diminution of the GDP and further destabilisation of economic flows (Aranđelović \& Gligorijević, 2008, p. 218-222). However, the most significant long-term consequence of sanctions is certainly the loss of the international market and trade links, at a very sensitive stage of development. The partial economic recovery that followed these events was halted in 1999 by the bombing of the Federal Republic of Yugoslavia by NATO members. The destruction of industrial capacites and infrastructure, the disruption of production and human casualties, reduced the material basis of development and destabilised already devastated economy. The process of rebuilding international economic relationships, with enormous financial damages done to businesses, was stopped again (Gligorijević, 1999).

The impact of negative factors on the economy of the Republic of Serbia, in this period, was most drastically reflected in the movement of GDP.

Table 2: Growth rate of the GDP of the Republic of Serbia in the period 1990-2000

\begin{tabular}{|l|c|c|c|c|c|c|c|c|c|c|c|}
\hline Year & $\mathbf{1 9 9 0}$ & $\mathbf{1 9 9 1}$ & $\mathbf{1 9 9 2}$ & $\mathbf{1 9 9 3}$ & $\mathbf{1 9 9 4}$ & $\mathbf{1 9 9 5}$ & $\mathbf{1 9 9 6}$ & $\mathbf{1 9 9 7}$ & $\mathbf{1 9 9 8}$ & $\mathbf{1 9 9 9}$ & $\mathbf{2 0 0 0}$ \\
\hline$\%$ & $-7,7$ & $-11,7$ & $-28,1$ & $-30,4$ & 2,6 & 5,7 & 4,7 & 7,4 & 2,4 & $-22,8$ & 5,7 \\
\hline
\end{tabular}

Source: Statistical Office of the Republic of Serbia, Statistical Yearbook of Serbia, 2008.

The recessionary flows started in 1990, continued in the following year with increased intensity, so the GDP was further reduced by more than $11 \%$. The decline of the social product reached its culmination in 1992 and 1993, with negative growth rates of $-28,1 \%$ and $-30,4 \%$, so in 1993 its amount was on the level of $44 \%$ of the 1990 GDP. In the following years, a partial recovery followed, thanks to the large-scale government investment that was partly the source of the sale of Telekom's part. By the end of 1998, there was an average annual growth in the GDP of about 4\%.

As the result of the NATO aggression, in 1999 there was a dramatic fall in the GDP of close to $-23 \%$, which, nullified the effects of economic growth from previous years: the GDP fell from \$25.51 billion in 1990 to \$ 10.47 billion in 2000 .

During this period, certain sectors of the economy reacted differently to the aforementioned adverse conditions, so significant changes in the structure of the social product took place. In the 1990s, on the one hand, there was a tendency of declining of share of the industry in the formation of the GDP of the Republic of Serbia, while, on the other hand, there was a slight increase in agriculture and dominance of the services sector. Namely, in 2000, the industry participated with $33.6 \%$, agriculture with $19.9 \%$, and the 
services sector with $46.5 \%$ in the formation of the GDP (Aranđelović \& Gligorijević, 2008, 233). This was obviously the beginning of an accelerated deformation of the economic structure.

During the 1990s, there were also significant changes in the ownership structure of the GDP. The institutional transformation of property, started in 1988 and continued on two occasions over the next decade, was accompanied by non-institutional forms of private enterprise emergence.

The private sector more easily endured turbulence from the beginning of this period relative to the social sector, so that, despite the absolute decline in the economic activity, it recorded an increase in relative share in the formation of the GDP. Its relative share rose from 13\% in 1990, to 40\% in 2000 (Statistical Yearbook of Serbia, 2002).

The recessionary flows, in the early 1990s, also had a significant impact on employment trends during this period. The number of employees decreased year after year, so that in 1993 it was down more than 12\% compared to 1991, or, in absolute terms, by 343,000 workers. This tendency, with slightly less intensity, continued until 2000, so in the Republic of Serbia, the number of employees were decreased by almost 700,000 over the whole period.

The decline in employment is mainly related to the social enterprise sector, despite the prohibition of layoffs during economic sanctions. The fall in employment was far greater, due to hidden unemployment. It is estimated that over $30 \%$ of employees were on paid leave, while a significant number of workers were hired in the private sector, employing around 9\% of the total number of workers in 1993. The number of workers in the private sector was realistically higher due to the growing gray and black labour market. In addition, the number of workers in the private sector increased continuously, reaching level of 321,000 , or $15.8 \%$ of total employees in 2000 (Federal Republic of Yugoslavia Selected Issues and Statistical Appendix, 2002, 46).

The number of the unemployed was steadily increasing during this period. The unemployment rate from $19.1 \%$ in 1990 increased to $29,2 \%$ in 2000 (an increase of more than 150,000 unemployed in absolute terms).

Table 3: Unemployment rate in the Republic of Serbia in the period 1990-2000

\begin{tabular}{|l|c|c|c|c|c|c|c|c|c|c|c|}
\hline Year & $\mathbf{1 9 9 0}$ & $\mathbf{1 9 9 1}$ & $\mathbf{1 9 9 2}$ & $\mathbf{1 9 9 3}$ & $\mathbf{1 9 9 4}$ & $\mathbf{1 9 9 5}$ & $\mathbf{1 9 9 6}$ & $\mathbf{1 9 9 7}$ & $\mathbf{1 9 9 8} *$ & $\mathbf{1 9 9 9}^{*}$ & $\mathbf{2 0 0 0}$ \\
\hline$\%$ & 19,1 & 21,0 & 22,2 & 22,6 & 22,7 & 24,2 & 25,4 & 25,4 & 26,3 & 27,2 & 29,2 \\
\hline
\end{tabular}

*Without Kosovo and Metohia

Source: Republican Institute for Labor Market.

The structure of the unemployed had the highest number of unskilled workers, although the fastest growth was recorded by the categories of skilled and highly skilled workers and those seeking employment for the first time. In this way, unemployment became a burning economic and social issue during this period.

Negative economic flows in the 1990s also reflected the foreign trade flows of the country. The total volume of foreign trade was in a continuous decline, with dynamics that was closer to or greater than the decline of the realised social product. In 1996, the volume of foreign trade was $43.8 \%$ of achieved in 1990 . The downward trend continued, so that in 2000, foreign trade was at the level of 39\%, compared to 1990 . 
The Import and export in this period had uneven contraction dynamics. The coverage of export by import was steadily declining, from $77.4 \%$ in 1990 to $46.8 \%$ in 2000

Table 4: Level of coverage of import by export in the Republic of Serbia in the period 1990-2000

\begin{tabular}{|l|c|c|c|c|c|c|c|c|c|c|c|}
\hline Year & $\mathbf{1 9 9 0}$ & $\mathbf{1 9 9 1}$ & $\mathbf{1 9 9 2}$ & $\mathbf{1 9 9 3} *$ & $\mathbf{1 9 9 4} *$ & $\mathbf{1 9 9 5}$ & $\mathbf{1 9 9 6}$ & $\mathbf{1 9 9 7}$ & $\mathbf{1 9 9 8}$ & $\mathbf{1 9 9 9}$ & $\mathbf{2 0 0 0}$ \\
\hline$\%$ & 77,4 & 86,5 & $\ldots$ & $\ldots$ & $\ldots$ & $\ldots$ & 45,8 & 56,2 & 60,8 & 47,5 & 46,8 \\
\hline
\end{tabular}

*The period of OUN sanctions

Source: Statistical Office of the Republic of Serbia, Statistical Yearbook of Serbia, 2008.

During this period, there were changes in the regional structure of export and import. The most important export market was still the European Union. The relative share of this market in total export from $47 \%$ in 1990 decreased to $42 \%$ in 2000 . Export to Eastern European countries also decreased from 25\% to $14 \%$. Second in importance is the market of former Yugoslav republics, with a relative export share of $30 \%$ in 2000 . In the regional import structure in 2000, the import from the European Union dominated with relative share of $40 \%$, while import share from Eastern European was 29\% and import share from the former Yugoslav republics was about 10\% (Statistical Yearbook of Yugoslavia 1997-2000 and Statistical Yearbook of Serbia 2000-2004).

\section{Conclusion}

The economic structure of the Republic of Serbia after the Second World War was formed under the influence of industrialisation, as a general development concept of the SFRY. Industrialisation in Serbia, with a particular focus on the development of heavy industry, led, by all indicators, to rapid and profound structural changes which were accompanied by high rates of economic growth, especially in the first fifteen years of post-war development. Until the early 1960s, this development concept had functioned as a unified and plan-coordinated process.

In the coming period of industrialisation, there was a radical shift in development priorities towards faster development of the light processing industry and agriculture, but with a gradual decrease in the share of accumulation and economic investment, as well as an increase in the share of personal consumption and non-economic investment in the distribution of the social product. The aim was to balance the economic structure, by reducing the gaps between agriculture and industry, as well as within industry (between production of production goods and consumer goods). However, the abrupt break with the logic of rapid development of the branches producing basic raw materials and energy contained the germ of basic structural disorders: faster growth in consumption relative to the dynamics of domestic product growth.

The declining growth rate of GDP and industrial production, with already evident balance of payments difficulties, a decrease in accumulation and domestic sources of investment, led to the creation of external imbalances, as another major structural deformation. The misdirected goals of the reform (decentralization of distribution, transfer of disposal and management of accumulation and investment from the state to the enterprises), through a more free market functioning in the country, has not been an adequate mechanism for eliminating these structural disproportions. 
The consequences of a sudden change in the focus of industrial development, through an increase in the relative share of branches of the processing industry, have resulted in faster growth of production of higher, compared to lower stages of processing. This process of change in the relations between the processing and base branches has resulted in a shortage of raw materials, incomplete use of certain processing capacities, an increase in the import of reproductive materials and a gradual creation of disproportions in the material structure of industrial production. The consequences of this are very pronounced under modern conditions.

The established industrial structure was aimed at satisfying domestic investment demand and realisation of the model of extensive growth, through a quantitative increase in production capacity. As such, it was chronically dependent on imports of raw materials from abroad, which, owing to marked inefficiency and non-competitiveness on the international market, generated a rise in borrowing due to a constant lack of export revenues.

Therefore, the Republic of Serbia, quite obviously, entered into transition processes with serious structural problems, the impact of which was most visible in the absence of economic growth.

\section{References}

Abramovitz, M. (1986). Catching Up, Forging Ahead, and Falling Behind. Journal of Economic History,

XLVI (2).

Aranđelović, Z., \& Gligorijević, Ž. (2008). Nacionalna ekonomija (National economy), Niš: Petrograf.

Chatterjee, S. (1995). Structural Change, Growth and Optimal Poverty Interventions. Asian Development Bank, Mimeo.

Chenery, H. B. (1960). Patterns of industrial growth. The American Economic Review, 50(4).

Chenery, H. B. (1975). The structuralist approach to development policy, American Economic Association.

Chenery, H., Robinson, S., \& Syrquin, M. (1986). Industrialization and growth: A comparative study. New York, NY: Oxford University Press.

Čobeljić, N. (1972). Privreda Jugoslavije, rast, struktura i funkcionisanje (Yugoslav economy, growth, structure functioning) knjiga prva (book one), Beograd: Savremena administrcija.

Ćorović, E. (2012). Uloga tekstilne industrije u procesu strukturnog prilagođavanja privrede Srbije. (The role of the textile industry in the process of structural adjustment of the Serbian economy) (doktorska disertacija) (Phd thesis), Niš: Ekonomski fakultet.

Domar, E. (1947). Essays in Theory of Economic Growt, New York: Oxford University Press.

Drbonjak, J. (2013). Nova reindustrijalizacija (New reindustrialization). preuzeto sa linka: http://www.ekonomskisavetdss.com/2013/09/-jovo-r-drobnjakreindustrija lizacijarealnost-ili-rec-koja-samo-lepo-zvuci/. 
European Central Bank (2016). Statistics. Preuzeto sa linka (taken from the link):

Fosu, A. (2010). Growth, Inequality and Poverty Reduction in Developing Countries: Recent Global Evidence. OECD, Development Centre Background Paper for the Global Development Outlook 2010, Shifting Wealth: Implications for Developmen.

Gligorijević Ž. \& Ćorović, E. (2019). Strukturne promene i novi model privrednog rasta Republike Srbije (Structural changes and a new model of economic growth in the Republic of Serbia). Niš: Ekonomki fakultet.

Gligorijević, Ž. (1999). Uticaj agresije NATO-a na svojinsku transformaciju jugoslovenske privrede (The Impact of NATO Aggression on the Property Transformation of the Yugoslav Economy). Ekonomske teme broj 1-2, Niš: Ekonomski fakultet.

Gligorijević, Ž. (2019). Ekonomika industrije (Industry Economics). Niš: SVEN.

Gligorijević, Ž. (1984). Strukturne disproporcije u privredi i nezaposlenost radnosposobnog stanovništva (Structural disproportions in the economy and unemployment of the working-age population). Ekonomika, 6/84. Niš: Društvo ekonomista.

Harod, R. (1948). Towards a Dynamic Economics. London: MacMillan.

Herrendorf, B., Rogerson, R., \& Valentinyi, A. (2014). Growth and structural transformation. In Aghion, P., \& Durlauf, S. (Eds.): Handbook of economic growth, vol. 2, pp. 855-941. Amsterdam \& New York: North Holland.

https://www.ecb.europa.eu/stats/html/index.en.html.

International Monetary Fund, (2002). Federal Republic of Yugoslavia - Selected Issues and Statistical Appendix, Washington.

Kruger, J. J. (2008). Productivity and structural change: A review of the literature. Journal of Economic Surveys, No: 22 (2), page 330-363.

Kuznets, S. (1957). Quantitative Aspects of the Economic Growth of Nations. Chicago: The University of Chicago Press.

Kuznets, S. (1966). Modern economic growth: Rate, structure, and spread. New Haven, CT: Yale University Press.

Kuznets, S. (1973). Modern economic growth: Findings and refections. American Economic Review, No: 63 (3), page 247-258.

Laitner, J. (2000). Structural Change and Economic Growth. The Review of Economic Studies Vol. 67, No. 3.

Landesmann, M. (2000). Structural Change in the Transition Economies, 1989 to 1999, Wien: WIIW working paper.

Lewis, W. A., (1954) Economic development with unlimited supplies of labour, The Manchester School, 22 (2).

Marsenić, D. (2003). Ekonomika Jugoslavije (Economics of Yugoslavia). Beograd: Ekonomski fakultet.

McMillan, M. S., \& Rodrik, D. (2011). Globalization, structural change and productivity growth. NBER Working Papers Series, No. 17143. 
Nelson, R. R., \& Phelps, E. S. (1966). Investment in humans, technological diffusion and economic growth, American Economic Review, LVI(2).

Ngai Rachel, L., \& Pissarides, C. (2007) Structural change in a multi-sector model of growth. American economic review, 97 (1).

Republički zavod za statistiku, (2000, 2002, 2004, 2007, 2008) Statistički godišnjak Srbije (Statistical Yearbook of Serbia) Beograd.

Rosić, I., (2002) Rast, strukturne promne i funkcionisanje privrede (Growth, structural change and the functioning of the economy). Kragujevac: Ekonomski fakultet.

Savezni zavod za statistiku (1997-2000). Statistički godišnjak Jugoslavije (Statistical yearbook of Yugoslavia). Beograd.

Savezni zavod za statitiku, (1976, 1977, 1987, 1991) Statistički godišnjak Jugoslavije (Statistical yearbook of Yugoslavia). Beograd

Savić, LJ., (2009). Srpska industrijalizacija za dvadesetprvi vek (Serbian industrialization for the twenty-first century). Industrija broj 1, Beograd: Ekonomki Institut.

Simonović, Z., \& Simonović, D. (2010). A review of agricultural policy of Serbia in the period of First Serbian Uprising to World War II (1804-1941). Facta universitatis - series: Economics and Organization, 7(4), 469-476.

Simonović, Z. (2014). Upravljanje agrarom Srbije u tranziciji. Institut za ekonomiku poljoprivrede, Beograd.

Stojanović, R. (1972). Veliki ekonomski sistemi, (Large economic systems). Beograd: Ekonomski fakultet.

Stojanović, R. (1977). Optimalna strategija privrednog razvoja (Optimal economic development strategy). Beograd: Savremena administracija i Institut za ekonomska istraživanja.

Svennilson, I. (1954). The Process of Economic Growth. in: Hagemann, H., Landesmann, M., Scazzieri, R., (eds.) The Economics of Structural Change, Volume III, Critical Writings, Edward Elgar, Aldershot. 